\title{
How Teachers' Perceptions Affect the Academic and Language Assessment of Immigrant Children
}

\author{
Sandra Figueiredo ${ }^{\mathrm{a} *}$, Margarida Alves Martins ${ }^{\mathrm{b}}$, Carlos Silva ${ }^{\mathrm{c}}$, Cristina \\ Simões ${ }^{\mathrm{d}}$ \\ * Corresponding author: Sandra Figueiredo, sandradfigueiredo@ua.pt \\ ${ }^{a}$ Universidade Autónoma de Lisboa-DPS, Lisbon, Portugal, sandradfigueiredo@ua.pt \\ ${ }^{b}$ ISPA-Instituto Universitário,Lisbon,Portugal,mmartins@ispa.pt \\ ${ }^{c}$ Universidade de Aveiro, Aveiro, Portugal, csilva@ua.pt \\ ISDOM, Marinha Grande, Portugal,p2748@isdom.pt
}

http://dx.doi.org/10.15405/epsbs.2016.05.10

Abstract

Recent research evidences inconsistencies in teachers' practice regarding skills assessment of L2 students. Scientific evidence supports that less experienced teachers have lower orientation toward multiple task-tests for non-native students. Research questions: Whether school teachers as having different teaching training and unequal teaching experience with non-native students perceive differently a four-skills scale. Purpose of the study: This study intends to analyse the importance degree between the four skills/tasks: reading, writing, speaking and listening, in the perspective of school teachers. Method: 77 teachers, aged 32-62, with (and without) experience in teaching and adapting materials for immigrant students, divided into six groups according to their scientific domain. Assessment tools included a scale for judgement of four academic tasks adapted from the original "Inventory of Undergraduate and Graduate Level: Reading, Writing, Speaking and Listening Tasks (Rosenfeld, Leung \& Ottman, 2001). Main Findings: 1) different degrees of importance attributed by teachers on tasks that should be included in academic and language test for immigrant students; 2) perceptions of teachers are determined by predictors in this order: scientific domain, experience with multicultural classes and lower prediction from teaching service and age; 3 ) different results between american and portuguese samples answering the same questionnaire.

(C) 2016 Published by Future Academy www.FutureAcademy.org.uk

Keywords: Teachers'experience, academic language skills, immigrant students, evaluation perceptions.

\section{Introduction}

The non-native school population has increased in the classrooms, especially considering immigration in the North American and European continents (Callahan \& Obenchain, 2013; Guo, 2013; Huddleston, Niessn \& Tjaden, 2013; Kolano \& King, 2015). However, teachers and education and psychology professionals in specific European and other contexts are not yet fully aware of the satisfactory academic profile expected of a native student according to the education level he is in (D’hondt, Eccles, Houtte et al., 2016; Sudkamp, Kaiser \& Moller, 2012; Pérez-Sabater, 2012). On the 
other hand, they also do not know, in a sustained way, the (expected) satisfactory profile teachers who evaluate foreign students are supposed to have (Kolano \& King, 2015; Rogers-Sirin, Ryce \& Sirin, 2013; Rosenfeld, Leung \& Ottman, 2001). When referring to the "knowledge" of the profiles of native teachers and of non-native students, we specifically focus on the perceptions and experience of teachers regarding the competence, the pace and the assessment of immigrant students (Levine-Rasky, 2001; Tejada, Pino, Tatar et al., 2012), in particular focusing on pupils newly arrived to schools, therefore with less exposure to the language of the host country.

Past studies indicate that some linguistic minorities can be affected by the expectations they feel on the part of their teachers and even peers (Creemers, 1994; Derwing, DeCorby, Ichikawa e al., 1999; Driessen \& Withagen, 1999; Schneider \& Yongsook, 1990). Recently, other authors (Brok, Tartwijk, Wubbels et al., 2010; Tatar \& Horenczyk, 2003) have been studying this influence on minority groups in schools and conclude that specific groups of students, according to their nationality, value and need more solid interpersonal relationships with their teachers, especially the second generation of immigrants (Brok et al., Callahan \& Obenchain, 2013). Native students do not seem to benefit from, or depend so much on, the relationships established with the expectations of teachers. On the other hand, different results (D’hondt, Eccles, Houtte et al., 2016; Schaedel, Freung, Azaiza et al., 2015) suggest that the perceptions and expectations of teachers can affect only some minority groups because they rely heavily on other factors, such as parental investment.

When valuing teachers' support capacity (Tejada, Pino, Tatar et al., 2012), the assessment relates to the well-established definition of measurements of different skills - reading, writing, speaking and listening skills - of the immigrant student population and these skills are then judged according to well-organized tasks that span across multiple cognitive levels estimated within the context of each of these skills (Bialystok, 2002; Cummins, 1980; Hinkel, 2012). These levels or cognitive dimensions are the problem regarding defining clearly the tests for school and higher education teachers (Hazenberg \& Hulstijn, 1996; Nation, 2001) in that the evaluation of a Second Language (L2) is a proven complex process because it is explained by a dynamic set of multiple variables according to the rate of processing, the students' exposure time to the language, the culture design of the nationality groups (Hinkel, 2012; Jia, Aaronson \& Wu, 2002), and the scientific field of teachers informing the orientation of their perceptions.

The scientific field of the teachers has been examined as an important predictor of differentiation of representations and practice in the classroom regarding the evaluation and teaching of linguistic minorities (Richard \& Rodgers, 2001, cited by Hinkel, 2012). The teachers of scientific areas more related to the natural sciences are more negligent with regard to the comprehensive teaching of the language, and value more the learning of the syllabus content of these subjects (Hinkel, 2012). The multiple language skills method has been a reality for teachers in the last two decades with regard to differentiated immigrant pupils in the classroom (Hinkel, 2012). The teaching of L2, which is different from Foreign Language (FL) teaching, doubled teachers' efforts to present it in a more cognitive perspective and not just foster the development of communication skills (Bialystok, 2002; Hinkel, 2012). According to studies conducted in the 1990s (Lightbown \& Spada, 1990; Schmidt, 1993, cited by Hinkel, 2012) analysing the four academic skills in the context of non-native students, the speaking 
(and listening) skill depended on exposure to L2 and valued, therefore, intensive immersion programmes. However, recent studies (indicated in Hinkel's meta-analysis, 2012) have shown that this is one among many variables that explain, for example, access to vocabulary and grammar awareness (Jia, Aaronson \& Wu, 2002).

Knowing what is more or less important, and the teaching methods (Hinkel, 2012) to use to develop the academic and language skills of immigrant students also depend on the teachers' experience regarding two aspects: school teaching experience (1) and teaching experience of non-native students (2). This study aims to analyze Portuguese teachers and students of non-mother tongue Portuguese (PLNM). Studies in the 1980s identified the main concerns of teachers starting their careers, therefore less experienced, and the experience of dealing with non-native students was not among those concerns (Veenman, 1984). On the contrary, recent studies indicate that assessing teachers' perceptions and competences involves the challenge of coping with diversity, which may lead to situations of “diversity-related burnout" (Taylor \& Sobel, 2001, cited by Tatar \& Horenczyk, 2003). Teachers' experience of multicultural groups has been studied more recently, highlighting the role of "typical teacher of non-mother tongue" or "teacher supporting L2 learning" binomial (Tejada, Pino, Tatar et al. 2012; Yoon, 2004).

This idea of support includes the expectations perceived by teachers and students (Tatar \& Horenczyk, 2003), which are not always facilitated by the type of social language that teachers use to identify and differentiate groups of students in the classroom (Devine, 2006; Marshall, 1996). The issue of teachers' expectations on the evaluation and learning of immigrant students started mainly with the concern to do valid tests for this population and seize the perceptions of evaluators (Rosenfeld, Leung \& Ottman, 2001), moving away from the older perspective of studies conducted in the school's organizational culture (Marshall, 1996). In what regards Europe, more scientific analysis of the teachers' perceptions is required, based on predictive testing to understand the inconsistencies believed to be made with non-native students in the classroom.

As regards the instruments to assess foreign population, the literature in the field of preparing Reference Frameworks and tests to evaluate cognitive and academic performance of immigrant pupils has shown inconsistencies in teachers' evaluation and teaching practices regarding the assessment of L2 learners' performance (Papgeorgiou, 2014; Pérez-Sabater, 2012). The Anglo-Saxon model is the one with more validated instruments in the L2 area, with a background of test review procedures that points to the constant concern with the type and validity of tasks to be used with linguistic minorities and in different school levels (Bachman, 2000; Bailey \& Huang, 2011). In the European context, the frameworks of reference are different and there is no consistent literature in the specific case of Portuguese immigration (Pires, 2009).

This study aims to identify the type and level of importance that teachers of educational levels ranging from pre-school to high education assign to tasks to specifically assess the academic competence and performance of non-native students. The ultimate goal is to match the type of tasks to effectively measured academic performance. The study examines the relevant areas for the creation of tasks in proficiency and performance evaluation tests as well as replicating the previous study by Rosenfeld, Leung and Ottman (2001) in the TOEFL review by using a scale of 42 items that identifies 
tasks and responsibilities in the areas of reading, writing, speaking and listening skills, at the university level. In this study, the target population consists of teachers of basic education and high school and aims to: 1) identify the most revealing tasks for the establishment of items in proficiency and competency tests; 2) assess the knowledge and representations that these teachers have about evaluation tests, according to age (a) length of service (b), and experience with multicultural classes (c).

\section{Method}

\subsection{Participants}

The study involved 77 teachers aged between 32 and 62 years $(M=47$ years, $S D=7.4)$, of whom 11 $(14.3 \%)$ were male and $60(77.9 \%)$ were female, with an average of 22 years teaching experience $(\mathrm{SD}=6.7)$. Teachers teach at nine schools/groupings in the district of Lisbon, with 9 being teachers of Portuguese language (11.7\%), 12 of FLs (15.6\%), 26 of Pre-school and Basic Education (33.8\%), 8 of Hard Sciences (10.4\%), 16 of History/Geography (20.8\%) and 3 of Visual Arts (3.9\%), distributed by the various levels of education (excluding higher education). 58 (75.3\%) have experience of multicultural classes and 16 (20.8\%) have never had non-native students in their classes. 46 (59.7\%) used Non-Mother Tongue Portuguese Language (PLNM) measures and 19 (24.7\%) admitted to never having used them.

ANOVA tests were carried out to compare results according to the participants' scientific domain and in relation to several variables: age, grade level, teaching experience, teaching experience with non-native students and experience with measures for second language learners. The results were: $\mathrm{F}(5,66)=3.518, \mathrm{p}=.001$ for the age variable; $\mathrm{F}(5,67)=16.161, \mathrm{p}=.000$ for the grade level; $\mathrm{F}(5,68)=$ $3.198, \mathrm{p}=.012$ for the teaching experience. No significant difference was found in the experience with non-native students (and measures used in their evaluation and learning).

\subsection{Instrument}

The Inventory of undergraduate and graduate level - reading, writing, speaking and listening tasks questionnaire by Rosenfeld, Leung and Ottman (2001) was used and adapted to the sample of Portuguese teachers. This questionnaire was originally developed by four scientific committees (framework teams) under the TOEFL and the Educational Testing Service in order to measure the importance, from the viewpoint of American university professors and students in education training courses, of the reading, writing, oral and listening tasks to be included in a test capable of assessing the academic competence and proficiency of non-native students. The original test has 42 items, of which we have adapted 40 distributed by the four scientific areas: reading (10 items), writing (10 items), speaking (10 items) and listening (10 items). The original test in the English version has no information about its reliability properties, but the Portuguese version has a high Cronbach's coefficient (.94). The exploratory factor analysis was then conducted and all items were considered like in the original study that asserted that, although some items scored below 3.5, they were not excluded from the scale. We used the cut-off point established by the authors of the original version - 3.5. All items that scored 
below 3.5 revealed that teachers do not consider the task of integrating an assessment test for nonnative students important.

The test was submitted to an exploratory factor analysis (EFA) to assess participants' answers and the factor structure of the test that was hypothesized as a four factor structure. The items with a factor loading of .40 or higher were used to define each factor. The Kaiser-Meyer-Olkin test showed that the sample size was adequate (.70) and the Bartlett test showed there was a good correlation index among the variables. As such, our acceptability rate allowed us to test our hypothesis $(p=.000)$. By excluding no items, 11 factors were found and the first factor received the highest upload of almost all items from the "reading", "writing", "speaking" and "listening" scales. Eleven eigenvalues were higher than 1, explaining $75 \%$ of total variance. This was not expected considering that the EFA was hypothesized as a four-factor dimension structure. The original study did not produce an EFA. Fourteen items were selected.

The main component analysis showed that almost all 40 items loaded on the first factor, which was not expected considering that the first factor should correspond to the first scale (of four scales) Reading. Items in this factor include items from the four academic skills. Three items (9. "Distinguish factual information from opinions"; 10. "Compare and contrast ideas in a single text and/or across texts", 11. "Synthesize ideas in a single text and/or across texts" ) from Reading scale loaded greatly only in the second factor.

\subsection{Procedure}

The data was collected in 2013 and 2015 in basic and high schools in the district of Lisbon. Contact was established with schools of the Lisbon district network to propose the study and disseminate the research aims. Communication with schools allowed identifying a vast group of teachers, which resulted in 77 teachers who fully completed the questionnaire. Following the informed consent and the demographic record of the selected school population, the questionnaire was answered and assessed (using points) according to the original test. Teachers responded to the questionnaire's forty questions on paper and returned it to the class Board and Department which, in turn, ensured it was returned to us. The procedure took place in the same way and in different academic periods in all schools.

The socio-demographic information was provided by the schools following informed consent after the beginning of each school year. The questionnaire was part of the empirical context of using linguistic and cognitive tests simultaneously with 108 immigrant students from different linguistic minorities who attended the same schools. Data were analysed using SPSS, version 21.

\section{Results}

We made statistical analyses using SPSS to determine univariate analysis of variance to identify significant differences between groups and effect size (1); and regression analysis using the stepwise method (2). 


\subsection{Univariate analysis of variance (ANOVA): effect size and post-hoc analyses}

\section{Age groups}

For all the items there was no substantial effect size. Cohen's benchmarks for statistical value of $\eta 2$ were established as norm (Cohen, 1988).

\section{Teaching Experience}

Reading: Regarding the ability "locate by skimming and scanning", the groups differed significantly $(p=.017 ; \eta 2=.113$ ). The group with the highest mean in this task was the one with most teaching experience (up to 35 years - $\mathrm{M}=4.36$ ) and there was a statistically significant difference between this group and the group with average experience (up to 25 years of teaching experience $M=3.68$ ). The group with less experience had a mean close to that of the most experienced group.

As for the item "Underline the important ideas in the text" the groups also behaved significantly differently $(\mathrm{p}=.020 ; \eta 2=.108)$ with regard to the value they placed on the item. Similarly, as in the previous task, more experienced teachers had the highest mean $(M=4.73)$ compared to the group who had up to 25 years of experience $(M=4.19)$.

A post-hoc (Tukey) test revealed significant differences among the groups of teachers with different experience levels $(\mathrm{p}<.05)$, with regard to differences in the specific Reading items: skimming and scanning strategy $(\mathrm{F}(2.68)=.725 ; \mathrm{p}=.017)$, and outlining important ideas strategy $(F(2.68)=3.164 ; p=.049)$. The differences were between teachers with larger experience (up to 35 years of teaching experience) and teachers with 25 years of experience. Again, there was no statistically significant difference between these groups and teachers with less teaching experience

Writing: Regarding the ability "time constraints", the groups differed significantly ( $p=.010 ; \eta 2$ $=.128$ ). The group with the highest mean in this task was the group who had more teaching experience (up to 35 years - $M=4,09$ ) and there was a statistically significant difference between this group and the group with average experience (up to 25 years of teaching experience - $M=3,51$ ). The group with less experience stood close to the mean of the most experienced group, just like in the Reading items, which showed differences in the perception behaviour of the groups.

A post-hoc (Tukey) test revealed significant differences among the groups of teachers with different experience levels $(\mathrm{p}<.05)$, considering differences only for the time constraints writing item $(\mathrm{F}(2.68)=4.396 ; \mathrm{p}=.022)$. The differences were between more experienced teachers (up to 35 years of teaching) and teachers with 25 years of experience. The groups' mean responses have been presented above. Again, the two groups had the same perception of items, just as in the Reading skill.

Listening: Only in the "recognition of the communicative intention" task, the groups differed significantly (considering the results for the $p$ value and effect size, $\eta 2$ ) in the results obtained in the "teaching experience" variable $(p=.036 ; \eta 2=.093)$. Again, and supported by the Tukey tests (post-hoc 
http://dx.doi.org/10.15405/epsbs.2016.05.10

eISSN: 2357-1330 / Corresponding Author: Sandra Figueiredo

Selection and peer-review under responsibility of the Organizing Committee of the conference

analyses), significant differences $(p<.05)$ only occurred among groups with up to 25 (3.78) and 35 years (4.32) teaching experience. The younger group's mean remained high and close to that of the older group, but there are no significant differences in the comparison between groups for this variable as well (see Table 1).

\section{Teaching Experience with foreign students}

There was significant effect size ( $\eta 2$ ranging between .060 and .120) in all the items, but only in some items in the reading and speaking skills. The groups differ depending on whether they have/have had PLNM classes or not.

Reading: Regarding the "outline important ideas" ability, the groups differed significantly ( $p=.044$; $\eta 2=.060$ ). A post-hoc (Tukey) test confirmed significant differences among the groups of teachers with different experience levels with foreign students $(p<.05)$, regarding differences in the outlining important ideas strategy $(\mathrm{F}(1.66)=4.224 ; \mathrm{p}=.044)$. The group with the highest mean in this task was the group that never had PLNM classes $(\mathrm{M}=4.73)$ and the group with experience of non-native students is the one that values the said item $(\mathrm{M}=4.30)$ the least. There were also differences between groups in this same item/task regarding the "teaching experience" variable, which suggests highly consistent results.

Speaking: Regarding the items "give instructions clearly" and "arguing", the groups also showed significantly different behaviour ( $\mathrm{p}=.014 ; \eta 2=.120, \mathrm{p}=.026 ; \eta 2=.072$, respectively per item). Similarly, as in the previous task, teachers with experience of foreign students (migrants and L2 context) have higher mean ( $M=4.47$ and 4.27, respectively) compared to the group without experience ( $M=3.75$ and 3.79 , respectively).

A post-hoc (Tukey) test confirmed the significant differences among the groups of teachers with different experience levels with non-native students in classroom $(\mathrm{p}<.05)$, regarding the differences for the only two Speaking items observed: giving directions and instructions $(\mathrm{F}(1.66)=1.937 ; p=.014)$ and structuring hypotheses $(\mathrm{F}(1.66)=1.365 ; p=026$, see Table 1$)$.

Still in the context of experience with non-native students' classes, in a context of learning Portuguese as L2, the same univariate analyses were conducted (effect size, comparison and means and Tukey test) to check the variable related to the experience factor: use or not of PLNM measures in the classroom (considering the group that has/had multicultural classes).

Differences were noted only regarding the task "reading based on synthesis of ideas", where the $\eta 2$ value was substantial $(p=.010 ; \eta 2=.106)$. Teachers who admitted failing to apply measures in their classes present the lower mean $(\mathrm{M}=3.22)$ below the cut-off point $(\mathrm{M}=.5)$, unlike the teachers who state having used measures to support PLNM $(\mathrm{M}=3.86)$. All data, checked with a statistically significant difference, on the group behaviour analysis for each item and factor are presented in table 1 . 
Table 1. Comparison among groups (means, pearson and effect sizes): teachers perceptions according to teaching service, experience with multicultural classes and L2 measures application.

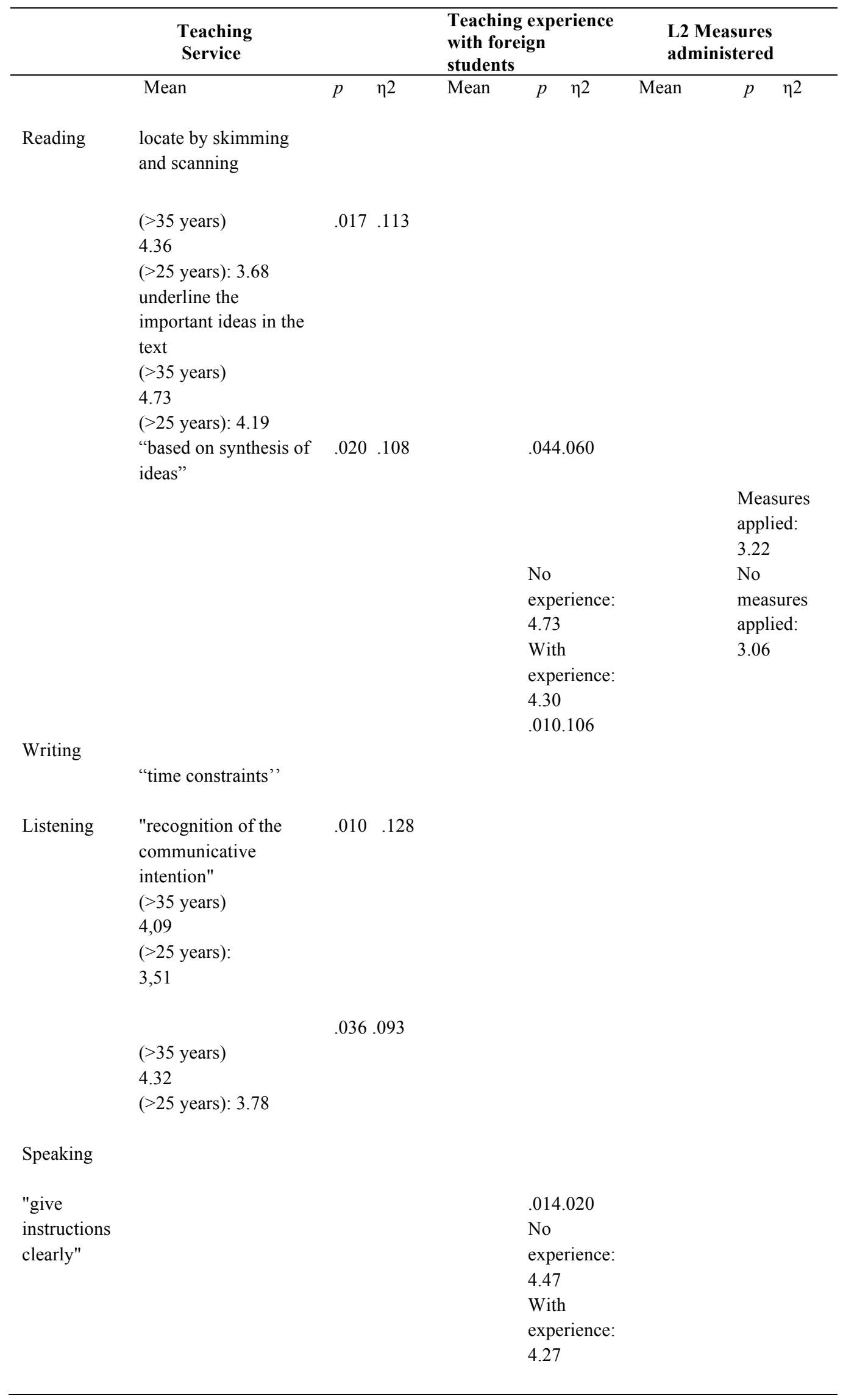


http://dx.doi.org/10.15405/epsbs.2016.05.10

eISSN: 2357-1330 / Corresponding Author: Sandra Figueiredo

Selection and peer-review under responsibility of the Organizing Committee of the conference

$\begin{array}{ll}\text { "arguing" } & .026 .072 \\ & \text { No } \\ & \text { experience: } \\ & 3.75 \\ \text { With } & \text { experience: } \\ & 3.79\end{array}$

\subsection{Linear Multiple Regression Analysis}

Considering the sequence of past results, and having particularly noted how the groups of subjects determined according to different independent variables behaved in the valuation of tasks of the four scientific areas, it was decided to resort to linear regression analysis to ascertain the main predictors among the group of independent variables under study using the stepwise method, and how the model is used to establish the importance of specific tasks to be given to non-native students by teachers in Portuguese schools (Lisbon district). Only the tasks that showed significant differences in the groups and significant effect sizes were considered, according to the results of the previous tests.

\section{Reading}

For the task "compare and contrast ideas in a single text and/or across texts" regression results also showed that the teachers' scientific domain variable has predictive value $(b=-.333, p=.009)$ but also the "experience with measures applied to foreign students" $(b=-.249, p=.041)$, as opposed to the other 3 factors - teaching experience, age, experience with foreign students in classes - where no significant predictive power was shown. The importance of that specific reading items is affected by the perceptions of the different teachers (by scientific domain). In order to clarify this result, and having examined the overall result (through a frequencies previous test) of the answers to all the items of the scale (14 factors), it was found that Portuguese language and FLs teachers are the ones who had more positive perceptions regarding all the tasks listed in the questionnaire. Teachers of other scientific fields value different items and attach less importance to items. The teaching areas are important factors in predicting tasks and enforcing them among linguistic minorities in schools. As for the other variable that the model shows as being the second and final model predictor, it appears that the negative experience of teachers (absence of experience) predicts lower application of measures for students inside the classroom. There were 2 reading tasks (theme identification and facts/opinions distinction) that regression analysis revealed as having no significant predictive value for any independent variables. The results are summarized in table 2.

\section{Writing}

Regarding both tasks "awareness of audience needs and write to a particular audience or reader" (1) and "time constraints" (2), results showed that only the teachers' scientific domain variable has predictive value (task 1: $b=-.261, p=.044$; task $2: b=-.613, p=.000$ ) as opposed to the other 4 factors teaching experience, age, experience with foreign students in classes, measures applied to foreign students in classroom - where no significant predictive power was found. Importance for that specific writing item is affected by the scientific domain of teachers, meaning that there are perceptions of 
teachers, according to the teaching area, that produce differences on the importance attributed to that task, for foreign/immigrant students. The results are summarized in table 2.

\section{Speaking}

For the tasks "questioning teacher" (1), "participation toward other students" (2) and "presentation toward other students" (3), results showed that only the teachers' scientific domain variable has maintained predictive value (task $1: b=-.421, p=.001$; task $2: b=-.335, p=.009$; task $2: b=-.365, p=.004$ ). For the task "giving instructions/directions" (4) results showed that experience with multicultural classes is the only predictor $(b=.270, p=.037)$. For the task "structuring hypotheses" (5), results showed that the teachers' scientific domain variable has maintained the predictive value $(b=-.389, p=.002)$, but also other variable emerged from the model as a predictor: age variable $(b=-.287, p=.017)$. In the ANOVAs the age variable did not display significant differences among the groups for any items.

\section{Listening}

For the task "recognize the speaker's attitudinal signals", results showed that the experience with measures for foreign students is the only predictor $(b=-, 272, p=.034)$. The importance of that item is affected by teachers' experience in dealing with pedagogical measures (considering the descriptive statistics of ANOVA, we determined that the teachers with experience of pedagogical measures attribute greater importance to this task than the group with no experience or knowledge of those measures). The results are summarized in table 2 .

Table 2. Linear regression analysis of tasks relevance (*dependent variables appeared in the prediction model).

\begin{tabular}{|c|c|c|}
\hline \multirow[t]{2}{*}{ Model } & \multicolumn{2}{|c|}{ Standardized coefficients } \\
\hline & Beta & Sig. \\
\hline \multicolumn{3}{|c|}{$\begin{array}{l}\text { Reading } \\
\text { compare and contrast ideas in a single text } \\
\text { and/or across texts (1) }\end{array}$} \\
\hline Scientific domain* & .333 & .009 \\
\hline \multicolumn{3}{|c|}{ Experience with L2 measures (2) } \\
\hline Scientific domain* & .249 & .041 \\
\hline \multicolumn{3}{|c|}{$\begin{array}{l}\text { Writing } \\
\text { awareness of audience needs and write to a } \\
\text { particular audience or reader (1) }\end{array}$} \\
\hline time constraints (1) & .261 & .044 \\
\hline Scientific domain* & .613 & .000 \\
\hline
\end{tabular}


http://dx.doi.org/10.15405/epsbs.2016.05.10

eISSN: 2357-1330 / Corresponding Author: Sandra Figueiredo

Selection and peer-review under responsibility of the Organizing Committee of the conference

Speaking

questioning teacher (1)

.421

.001

participation toward other students

.335

.009

presentation toward other students (3)

.365

.004

Scientific domain*

giving instructions/directions (4)

.270

Experience with multicultural students*

structuring hypotheses (5)

Scientific domain*

Age*

Listening

recognize the speaker's attitudinal signals (1)

L2 measures administered*

.272

.034

\section{Discussion}

The results respond to the questions of this study. With regard to the first question, it turns out that Portuguese teachers differentiate tasks as being more or less relevant throughout the four specific academic areas in the creation of items in proficiency and competence tests of learners of Portuguese as L2. There are differences in assigning importance to items within each academic area (reading, writing, speaking and listening comprehension) but there are also differences in the groups regarding perception of specific items, as the previous results show. It was found that the less valued items lie in the writing area (item associated with the ability to write according to the type of audience) and in speaking (item related to the ability of structuring hypotheses during speech - arguments). These data support previous results (Gebhardt, Chen, Graham et al., 2013) and show that one of the greatest writing difficulties of L2 learners is to produce texts related to the specific contents of the subjects.

This difficulty is related to the teachers' instruction method, which focuses on grammar and underestimates the sociolinguistic sense, in this case the skill to write according to a specific audience. If the difficulties lie in this aspect of writing (audience awareness), then the explanation is the type of instruction and the teachers who underestimate this item (one of the weakest observed in this study) indicate that they maintain an inadequate teaching method. According to Gebhardt et al., the way teachers perceive the teaching of language rules generated problems to the correct teaching of needs in the writing skill, like knowing how to write properly for different publics.

It should be noted that in a previous study (Shanahan, 1992), it has been highlighted that writing depends, for its proper development, on a great awareness of the audience for which one is writing. This study stresses a problem related to the perception of teachers that directly affects the teaching done. This study demonstrates that teachers effectively value this type of skill less (writing skills according to the audience) and for this reason it appears as one of the items with a lower mean. It seems that for this kind of task, Foreign Language teachers value it less than the Portuguese language teachers, and in the same proportion regarding the valuing of grammar rules. 
FLs teachers are the ones who undervalue these two aspects of writing the most, when they should be the most sensitive to the grammar question and sociolinguistics of the audience. However, these data are in line with a meta-analysis study conducted by Graham and Peri (2007) who identified the priorities of teachers in the writing teaching tasks as being teaching strategies and 'peer assistance' to the detriment of grammar, pre-writing activities and processing aspects in texts written by the students. According to studies conducted in the eighties (Scarcella, 1984), L2 writers have major problems in writing for specific audiences, which is related to "attention engaging" (p. 671) during the writing task. One cause may be related to the subject's incomplete proficiency in Mother Tongue (Khuwaileh \& Shoumali, 2000) and to difference in cognitive processing (and therefore different strategies) in the contexts of Mother Tongue and L2 (Silva, 1993).

Over the last decade, L2 studies started to focus more on issues related to the writing skill as regards planning and processing ability, common to writing and speaking (Khuwaileh \& Shoumali), therefore more focused on specific language issues and not on aspects of social and professional communication as in studies in the nineties (Scott, 1996): the principles and priorities of evaluating the writing of FLs and L2 learners by FLs teachers was not informed by the "language-specific" aspect (p. 1). In this study, these two dimensions common to the two skills are the most undervalued by the Portuguese teachers, which probably justifies the shift in focus in L2 research. In addition, there is the analysis of grammatical and textual cohesion mistakes that authors like Khuwaileh and Shoumali found in texts written by L2 learners.

In what regards the relevance of tasks indicating what kind of items a L2 evaluation test must include, one finds that the strongest items are in reading (understanding teachers' instructions and identifying the topic of the text, for example) and listening comprehension (understanding teachers' instructions, for example). These results are consistent with Brown's conclusions (2009), who found that teachers have perceptions of the tasks more focused on understanding the errors (language use) and on correcting them, therefore on the more "communicative classroom" aspect, which explains the valuing we found of items that focus on understanding teachers' directions in class. The "communicative classroom" aspect is productive if expanded in the direction of "communicative performance" (Bygate, Swain \& Skehan, 2013), i.e. a teaching context in the classroom that extends the transfer of cognitive strategies between skills (DeKeyser, 2007). Understanding (listening) instructions and reading them (reading comprehension) are valued equivalently in this study because there is a tested cognitive relationship between these two tasks/skills (Hinkel, 2006). We are facing Hinkel's $(2006 ; 2012)$ multiple language skills approach that has been addressed before by several authors but in the terminology of the common transfer of skills during the learning process in a L2 context (DeKeyser, 2007; Ellis, 2003; Van Patten, 2007).

Cognitive strategies such as organization of speech, fluency, and inferences can be common to reading and listening comprehension, which promotes more effective learning due to the transfer of cognitive skills across the four foundational skills than actually focusing on the exclusive use of a topdown or bottom-up teaching approach (Hinkel, 2006).

The positive correlation between reading and listening comprehension tasks is supported by studies by Zeeland and Schmitt (2013) and by Harding, Alderson and Brunfaut (2015) who, in the 
context of English as L2, identify common cognitive processes of native and non-native students in tasks to evaluate listening and reading, but with greater significance to L2 learners. Also Chien, Palau and Sun (2014) conclude there is a close relationship between cognitive strategies (interdependence) of writing and reading.

On the other hand, teachers value these skills (reading and listening) as they are skills that involve vocabulary retention (not exactly production), which is the area where the biggest problems for L2 learners are to be found (August, Carlo, Dressler et al., 2005; Lesaux \& Kieffer, 2010) and which allows students to know the language of the text (note how the item "identifying the topic of the text" is considered to be relevant) and access the reading scheme (Eskey, 2002). Still, with particular reference to listening comprehension in L2, the results are consistent with studies by Hasan (2010), Siegel (2013) and Carrier (2003), who analyse the teachers' explicit signs/instructions during listening comprehension exercises as being prominent. The relevance of tasks within each of the four fields relates primarily to the acquisition of content and language schema of the text, no longer focused (in the bottom-up method) on grammar isolated aspects and devoid of connection with the explicit techniques of instruction and authenticity of the input (Bygate \& Skehan, 2010; Siegel, 2013;Van Patten, 2007; Vandergrift, 2003).

Also within question 1 of the study, with regard to the correlation between the four core skills, the poor correlation between "integration" (compare and contrast ideas within a text or through various texts; and synthesize ideas within a text or through various texts) and all items from the same factor to which it belongs - reading - suggests a lack of consistency in the range of items related to reading. Teachers seem to be dispersed regarding the importance paid to the tasks assigned to the reading aspect, as the original questionnaire proposes. The ability to compare and contrast texts should be related to good writing indexes, which implies an inherent correlation between reading and writing (Grabe, 2003), but should also be an important predictor of the acquisition of described schema in different texts, since it is a skill potentiated by comparison and contrast along different texts (Grabe).

A negative correlation was also found between writing and reading items, as well as low correlation, although not negative, between specific reading tasks (location and basic understanding) and writing (linguistic rules) in the relationship with listening comprehension (understanding the main ideas and recognition of the communicative functions of the speaker).

On the one hand, this result is also partially in conflict with the study by Cho, Rijmen and Novak (2013) who, having applied the TOEFL IBT, like this study, found consistency in the items and respective skills through the difficulty recognized by teachers evaluating the tasks belonging to the four areas (reading, writing, listening and speaking). On the other hand, the same study detected specific problems highlighted in the relationship between reading and listening skills (Cho, Rijmen \& Novak, 2013).

With regard to the negative correlation between specific items of writing and reading, which would not be expected given the known interdependence relationship between these skills (Chien, Palau \& Sun, 2014), it is curious we have evidence that there is inconsistency in teachers' practices to promote non-native students' learning, as the relationship between reading and writing skills is very strong and proven (Shanahan, 2008). However, this easy correlation assumption goes back to the 
premise of the eighties when it was believed that the cognitive processes underlying reading and written skills in Mother Tongue were the same as in the L2 context. Graber (2003) focuses on this premise as founder of the idea of a direct correlation advocated by the authors of the following decade (Carson, 1990; Flahive \& Bailey, 1993). The author poses the question to assess the relationship, in L2, between those two skills, but not as a direct correlation. Also Shanahan (2008) analyses the relationship between the four skills but aligning the writing and reading, underlining the late acquisition of the former. And above all making writing dependent and benefiting from acquisitions and processes learned with other skills, highlighting the role of reading and speaking skills. It reveals that there is, however, clear intersections among all skills and that there are subareas (dimensions in each skill) that may have higher correlation and prediction than others between writing and reading (i.e. word decoding).

We started from the same principle in this study because our results explain how some items contradict the transversal relationship equation between skills. However, the same study (Shanahan) found that the speaking and writing skill in progress is parallel, particularly with implications for the acquisition of grammar rules that cut across both skills in the L2 context.

In fact, the author states that the most recent studies have confirmed the role of speaking for reading and not only of writing for reading and vice versa, in a different proportion of the one observed in the Mother Tongue context. Also, Ball (2003) concluded in his study that younger children (grades 3-6) are the ones who benefit most in reading using their speaking skills, dismissing the explanation of the largest prediction of writing for success in reading. The data seem to confirm this relationship (overlapping) in that the correlations are high and positive between such writing items (linguistic rules) and speaking skills (fluency and grammar rules).

Age is the factor that differs less between groups in univariate analysis of variance, except for the regression analysis test that shows the predictive influence of the age of teachers only to explain their choice of the task referring to the ability to reason within the speaking skill. In fact, there are few studies that examine this correlation (age factor) and usually authors (Kanno \& Stuart, 2011; Tsui, 2003) focus on the differentiation of experiences about teaching L2 between teachers at an early stage in their careers and more experienced ones. They conclude that younger teachers are at a stage of learning teaching and concepts processes, before actually implementing the tasks and processes (Kanno $\&$ Stuart).

It was only in the last two decades that analysis of the cognition of teachers on the actual teaching started, and very recently in the specific area of teaching content to non-native students (Horwitz, 1985; 2014; Johnson, 1994; Liu \& Fisher, 2006; Tsui, 2007), and without the longitudinal dimension of studies that are able to assess the modification of knowledge and practices of those teachers. Regardless of the area, but dependent on age, teachers begin by being more focused on solving classroom management problems, and only the more experienced care for language tasks in a L2 context (Nunan, 1992). In this study, age was not a significant variable in the comparative analysis of groups of teachers in the evaluation of the tasks for the four major skills of non-native students. However, compared to the study by Rosenfeld, Leung and Ottman (2001), younger teachers in this 
study are the ones who perceive fewer items in the tasks, especially in the speaking skill. Younger Portuguese teachers value more tasks, which attests their increased awareness compared to that of American teachers in the same assessed context of choosing relevant tasks for non-native students. On the other hand, younger teachers (and students in teaching training courses) in the previous study, as the younger teachers in the Portuguese study, devalue the writing tasks in a similar way, exactly in the audience item (writing for different audiences).

Isaacs and Thomson (2013) corroborate the specific situation of the preparation of the most inexperienced teachers, concluding that they are the teachers who find it most difficult to distinguish items within the test ranges.

Regarding the other variable - experience with multicultural groups - it was also found that it has predictive value (linear regressive analysis) for the implementation of action measures in non-native students, that is, less experience is associated with lower capacity and initiative to apply measures in PLNM. These results corroborate studies of the past two decades that reveal that inexperience in a L2 teaching context creates serious ambiguities and conceptual errors about how to teach and what materials to use in class with immigrant students (Horwitz, 1988; 2014; Kern, 1995; Mantle-Bromlwy, 1995; Peacock, 2001; Samimy \& Lee, 1997). Indeed, studies insist on distinguishing teachers in a preservice situation and real teachers in a L2 context, and the authors (Bree, Hird, Milton et al.,22001;Peacock, 2001) concluded that younger teachers at the start of their careers have more mistaken beliefs about teaching techniques and the learning priorities of non-native students. The same authors found that less experienced teachers with little contact with multicultural classes (or without any contact) are the teachers who characterize L2 teaching as focused exclusively on teaching grammar and vocabulary at the expense of other skills.

This study's results are partially in accordance with the data of international studies (Bree, Hird, Milton et al., 2001; Horwitz, 1985; Peacock, 2001) of the nineties and forward, in that Portuguese teachers devalue tasks related to the assessment and teaching of language rules, while agreeing with items that focus on vocabulary. Reading and listening comprehension, especially of test questions and written instructions, are the priorities, as noted, of the Portuguese teacher sample. On the other hand, in the groups within the Portuguese sample, teachers with less experience (the younger ones) do not differ from the more experienced ones when determining the reading tasks, which may denote less capacity to differentiate assessment and teaching tasks in general. Also, on the power of the variables referred to in Question 2 of this study, other authors value the analysis of the experience with multicultural groups (Flores \& Smith, 2009; Lee \& Oxelson, 2006; Pettit, 2011) and other factors, such as length of service and training for L2 teaching, (Flores \& Smith, 2009) for professionals to develop positive attitudes towards L2 education and the maintenance of Mother Tongue students as something important for the L2 development process (Bialystok, 2002; Cummins, 1980; Hinkel, 2012; Lee \& Oxelson).

The experience of implementing measures in non-native students was an important variable in this study to explain tasks valuation differences, but as a predicting variable. These results contradict previous studies that assert the importance of experience with linguistic diverse classes to build 
teachers' favourable attitudes towards the teaching of L2 learners (Karabenick \& Noda, 2004; Reeves, 2006; García-Nevarez, Stafford, Arias, 2005). Teachers with no experience in this area may develop representation problems on the needs of these students and the need to differentiate groups of learners (immigrants, refugees and bilingual), for which reason research in this topic is important to understand the lack of perception of teachers from any scientific area (Freeman, 1975; Karabenick \& Noda; Reeves, 2006). Since the diversity of the teachers' scientific areas is found mainly in high school, we find studies that corroborate the problem of the ill-preparation of those teachers, which has serious implications for the development of L2 in minorities within the classroom (Hansen-Thomas \& Cavagnetto, 2010; Rubinstein-Avila \& Lee, 2014).

Freeman (1975) confirms that prior knowledge of teachers is crucial in attitudes and practices within the classroom with non-native students because this prior knowledge encompasses predispositions and socio-cultural ideas. The diversity of linguistic minorities is increasingly broad and challenging. However, it was confirmed that teachers with no experience with measures/materials are those with lower means in assessing the relevance of the tasks. And regardless of length of service and experience with multicultural classes, experience with implementing L2 teaching measures/materials is a predictor variable only for listening comprehension with regard to the item "recognize attitudinal signals in the interlocutor" (i.e. communicative functions). Again, listening tasks appear to be highly valued by Portuguese teachers, confirming the research trend on L2 teaching methods that recognize the interdependencies of cognitive processes between listening and reading, as mentioned above (Brown, 2009; Bygate, Swain \& Skehan, 2013; DeKeyser, 2007; Harding, Alderson \& Brunfaut, 2015; Zeeland \& Schmitt; 2013).

The results presented in this study are an important contribution especially in two aspects: the analysis of teachers' perception of relevant tasks in L2 is pioneer in Portugal. On the other hand, it presents a corpus of results that corroborate and contrast those of previous international studies, with implications for education and concepts of practices that teachers from various scientific fields reveal about L2 teaching and the type of tasks to consider in tests and in the classroom.

The data suggest that teachers may be developing inadequate practices and concepts, especially considering the differences according to scientific field and high school level; that they undervalue the grammar component of all skills to be developed by the students; that they overemphasize listening comprehension and its relationship with reading; that they follow closely a L2 teaching model (originally of American design, Horwitz, 1985) but only basic education teachers (for students aged 411 years); and that they have poor notions regarding L2 tasks and evaluation tests, in general.

\section{Acknowledgements}

This work was supported by the Foundation for Science and Technology (FCT) under the Grant $\mathrm{n}^{\circ}{ }^{\mathrm{o}}$ SFRH/BPD/86618/2012; and Center of Psychology Research of Universidade Autónoma de Lisboa, Lisbon Portugal. 


\section{References}

Alderson, C., Brunfaut, T., \& Harding, L. (2015). Towards a Theory of Diagnosis in Second and Foreign Language Assessment: Insights from Professional Practice Across Diverse Fields. Applied Psycholinguistics. http://applij.oxfordjournals.org/content/early/2014/01/03/applin.amt046.abstract

August, D., Carlo, M., Dressler, C. \& Snow, C. (2005). The Critical Role of Vocabulary Development for English Language Learners. Learning Disabilities Research \& Practice, 20,50-57. doi: 10.1111/j.15405826.2005.00120.x

Bachman, L. (2000). Modern language testing at the turn of the century: assuring that what we count counts. Language Testing, 17, 1 1-42.

Bailey, A., \& Huang, B. (2011). Do current English language development/proficiency standards reflect the English needed for success in school? Language Testing, 28(3), 343-365.

Ball, S. (2003). Class Strategies and the Education Market: The Middle Classes and Social Advantage. London and New York. Routledge Falmer.

Bialystok, E. (2002). Acquisition of literacy in bilingual children: A framework for research. Language learning 52(1), 159-199.

Bree, M., Hird, B., Milton, M., Oliver, R., \& Thwaite, A. (2001). Making sense of language teaching: teachers' principles and classroom practices. Applied Linguistics, 22(4), 470-501. doi: 10.1093/applin/22.4.470

Brown, A. (2009). Students' and Teachers' Perceptions of Effective Foreign Language Teaching: A Comparison of Ideals. The Modern Language Journal, 93, 46-60. doi: 10.1111/j.1540-4781.2009.00827.x

den Brok, P., van Tartwijk, J., Wubbels, T., \& Veldman, I. (2010), The differential effect of the teacher-student interpersonal relationship on student outcomes for students with different ethnic backgrounds. British Journal of Educational Psychology, 80, 199-221. doi: 10.1348/000709909X465632

Bygate, M., Swain , M., \& Skehan, P. (2013). Researching Pedagogic Tasks: Second Language Learning, Teaching, and Testing. London and New York: Routeledge.

Callahan, R., \& Obenchain, K. (2013). Bridging Worlds in the Social Studies Classroom: Teachers' Practices and Latino Immigrant Youths' Civic and Political Development. Sociol Stud Child Youth. 16, 97-123. doi: 10.1108/S1537-4661(2013)0000016009

Carrier, K. (2003). Improving High School English Language Learners' Second Language Listening Through Strategy Instruction. Bilingual Research Journal: The Journal of the National Association for Bilingual Education, 27(3), 383-408.

Chien, K., Palau, V., \& Sun, M. (2014). Reading and Writing Achievement Test for Advanced 1 Students in the Community English Program. Teachers College, Columbia University.

Cho, Y., Rijmen, F., \& Novák, J. (2013). Investigating the effects of prompt characteristics on the comparability of TOEFL iBT ${ }^{\mathrm{TM}}$ integrated writing tasks. Language Testing, 30(4), 513-534.

Creemers, B. (1994). The Effect Classroom. London: Cassell.

Cummins, J. (1980). The Cross-Lingual Dimensions of Language Proficiency: Implications for Bilingual Education and the Optimal Age Issue. TESOL Quarterly, 14(2),175-187.

Cummins, J. (2012). The intersection of cognitive and sociocultural factors in the development of reading comprehension among immigrant students. Reading and Writing, 25 (8), 1973-1990.

Devine, D. (2006). Welcome to the celtic tiger? teacher responses to immigration and increasing ethnic diversity in Irish schools. International Studies in Sociology of Education, 15 (1).

DeKeyser, R. (2007). Practice in a Second Language: Perspectives from Applied Linguistics and Cognitive Psychology. Cambridge University Press.

Derwing, T., DeCorby, E., Ichikawa, J., \& Jamieson, K. (1999). Some Factors That Affect the Success of ESL High School Students. The Canadian Modern Language Review. DOI: http://dx.doi.org/10.3138/cmlr.55.4.532

D'Hont, F., Eccles, J., Van Houtte, M., \& Stevens, P. (2016). Perceived Ethnic Discrimination by Teachers and Ethnic Minority Students' Academic Futility: Can Parents Prepare Their Youth for Better or for Worse? Journal of Youth and Adolescence, 1-15.

Driessen, G., \& Withagen, V. (1999).Language varieties and educational achievement of indigenous primary school pupils. Language Culture and Curriculum, 12(1), 1-22.

Ellis, R. (2003). Task-based Language Learning and Teaching. Oxford: Oxford University Press.

Eskey, D. E. (2002). Reading and the Teaching of L2 Reading. TESOL Journal, 11, 5-9. doi: 10.1002/j.19493533.2002.tb00060.x

Flahive, D., \& Bailey, N. (1993). Exploring reading/writing relationships in adult second language learners. Reading in the composition classroom, 128-140.

Flores, B., \& Smith, H. (2009). Teachers' Characteristics and Attitudinal Beliefs About Linguistic and Cultural Diversity. Bilingual Research Journal: The Journal of the National Association for Bilingual Education, 31(1),1-2.

Freeman, D. (1975). The Acquisition of Grammatical Morphemes by Adult ESL Students. TESOL Quarterly, 9(4), 409-419.

García-Nevarez, A., Stafford, E., \& Arias, B. (2005). Arizona Elementary Teachers' Attitudes Toward English Language Learners and the Use of Spanish in Classroom Instruction. Bilingual Research Journal, 29(2), 295317. DOI: $10.1080 / 15235882.2005 .10162837$

Gebhrardt, R., \& Gebhrardt, B. (2013). Academic Advancement in Composition Studies: Scholarship, Publication. New York and London: Routledge. 
Grabe, W. (2003). Reading and Writing Relations: Second Language Perspectives on Research and Practice. In B. Kroll (Ed.), Exploring the Dynamics of Second Language Writing (pp. 242-262). USA: Cambridge Applied Linguistics.

Guo, Y. (2013). Language Policies and Programs for Adult Immigrants in Canada: A Critical Analysis. Canadian Ethnic Studies, 45(1/2), 23-41.DOI: 10.1353/ces.2013.0022

Hansen-Thomas' H., \& Cavagnetto, A. (2010). What Do Mainstream Middle School Teachers Think About Their English Language Learners? A Tri-State Case Study. Bilingual Research Journal: The Journal of the National Association for Bilingual Education, 33(2), 249-266. DOI:10.1080/15235882.2010.502803

Hasan, A. (2010). Learners' Perceptions of Listening Comprehension Problems, Language, Culture and Curriculum, 13(2), 137-153, DOI: 10.1080/07908310008666595

Hazenberg, S., \& Hulstijn, J. (1996). Defining a minimal receptive second-language vocabulary for non-native university students: An empirical investigation. Applied Linguistics, 17, 145-163. doi:10.1093/applin/17.2.145.

Hinkel, E. (2006). Current Perspectives on Teaching the Four Skills. TESOL Quarterly, 40, 109-131. doi: $10.2307 / 40264513$

Hinkel, E. (2012). Cognitive-code learning. Encyclopedia of the Sciences of Learning. USA: Springer.

Horenczyk, G., \& Tatar, M. (2002).Teachers' attitudes toward multiculturalism and their perceptions of the school organizational culture. Teaching and Teacher Education, 18(4), 435-445.

Horwitz, E. (1985). Using Student Beliefs About Language Learning and Teaching in the Foreign Language Methods Course. Foreign Language Annals, 18, 333-340. doi: 10.1111/j.1944-9720.1985.tb01811.x

Horwitz, E. (2014). Becoming a Language Teacher: A Practical Guide to Second Language Learning and Teaching. The CATESOL Journal, 25(1), 163-192.

Hudleston, T., Niessen, J., \& Tjaden, J. (2013). Using EU Indicators of Immigrant Integration. Report. Belgium: Home Affairs.

Jia, G., Aaronson, D., \& Wu, Y. (2002). Long-term language attainment of bilingual immigrants: Predictive variables and language group diferences. Applied Psycholinguistics, 23(4), 599-621.

Johnson, K. (1994). The emerging beliefs and instructional practices of preservice English as a second language teachers. Teaching and Teacher Education, 10(4), 439-452.

Kanno, Y., \& Stuart, C. (2011). Learning to Become a Second Language Teacher: Identities-in-Practice. The Modern Language Journal, 95, 236-252. doi: 10.1111/j.1540-4781.2011.01178.x

Karabenick, S., \& Noda, P. (2004). Professional Development Implications of Teachers' Beliefs and Attitudes Toward English Language Learners. Bilingual Research Journal, 28(1), 55-75, DOI: $10.1080 / 15235882.2004 .10162612$

Kern, R. (1995). Students' and Teachers' Beliefs About Language Learning. Foreign Language Annals, 28, 71-92. doi: 10.1111/j.1944-9720.1995.tb00770.x

Khuwaileh, A., \& Shoumali, A. (2000).Writing errors: a study of the writing ability of Arab learners of academic English and Arabic at university. Language, Culture and curriculum, 13(2), 174-183.

Kolano, L., \& King, E. (2015). Preservice Teachers' Perceived Beliefs towards English Language Learners:

Can a Single Course Change Attitudes? Issues in Teacher Education. Issues in Education, 24(2), 3.

Lee, J., \& Oxelson, E. (2006). "It's Not My Job": K-12 Teacher Attitudes Toward Students' Heritage Language Maintenance. Bilingual Research Journal: The Journal of the National Association for Bilingual Education, $30(2), 453-477$.

Lesaux, N., \& Kieffer, M. (2010). Exploring Sources of Reading Comprehension Difficulties Among Language Minority Learners and Their Classmates in Early Adolescence. Am Educ Res Journal, 47(3), 596-632.

Levine-Rasky, C. (2001). Identifying the prospective multicultural educator: Three signposts, three portraits.The Urban Review, 33(4), 291-319.

Liu, Y., \& Fisher, L. (2006). The development patterns of modern foreign language student teachers' conceptions of self and their explanations about change: three cases. Teacher Development: An international journal of teachers' professional development, 10(3), 343-360.

Mantle-Bromley, C. (1995), Positive Attitudes and Realistic Beliefs: Links to Proficiency. The Modern Language Journal, 79, 372-386. doi: 10.1111/j.1540-4781.1995.tb01114.x

Marshall, C., Patterson, J., Rogers, D., \& Steele, J. (1996). Caring as Career: An Alternative Perspective for Educational Administration. Educational Administration Quarterly, 32( 2), 271-294.

Nation, I. (2001). Learning vocabulary in another language. Ernst Klett Sprachen.

Nunan, D. (1992). Research Methods in Language Learning. USA: Cambridge University Press.

Peacock, M. (2001). Pre-service ESL teachers' beliefs about second language learning: a longitudinal study. System, 29, 177-195.

Pérez-Sabater, C. (2012). A Pioneer Study on Online Learning Environments Following the Common European Framework of Reference for Languages. Procedia - Social and Behavioral Sciences, 46, 1948-1955. doi:10.1016/j.sbspro.2012.05.409

Pettit, S. (2011). Teachers' Beliefs About English Language Learners in the Mainstream Classroom: A Review of the Literature. International Multilingual Research Journal, 5(2), 123-147.

Pires, S. (2009). A segunda geração de imigrantes em Portugal e a diferenciação do percurso escolar: Jovens de origem cabo-verdiana versus jovens de origem Hindu-indiana. $\mathrm{PhD}$ dissertation. Portugal: Alto Comissariado para a Imigração e Diálogo Intercultural, IP.

Reeves, J. (2006). Secondary Teacher Attitudes Toward Including English-Language Learners in Mainstream Classrooms. The Journal of Educational Research, 99(3), 131-143. 
Rogers-Sirin, L., Ryce, P., \& Sirin, S. (2013). Acculturation, Acculturative Stress, and Cultural Mismatch and Their Influences on Immigrant Children and Adolescents' Well-Being. Series Advances in Immigrant Family Research, 1, 11-30.

Rosenfeld, M., Leung, S., \& Oltman, P. (2001). TOEFL monograph series: The reading, writing, speaking, and listening tasks important for academic success at the undergraduate and graduate levels. Toefl Monograph Series MS-21. Princeton, NJ: Educational Testing Service.

Rubinstein-Ávila, E., \& Lee, E. (2014). Secondary Teachers and English Language Learners (ELLs): Attitudes, Preparation and Implications. The Clearing House: A Journal of Educational Strategies, Issues and Ideas, 87(5), 187191. DOI:10.1080/00098655.2014.910162

Samimy, K., \& Lee, Y. (1997). Beliefs about language learning: Perspectives of first-year Chinese learners and their instructors. Journal-Chinese Language Teachers Association, 32, 40-60.

Scarcella, R. (1984). How Writers Orient Their Readers in Expository Essays: A Comparative Study of Native and Non-Native English Writers. TESOL Quarterly, 18(4), 671-688.

Schaedel, B., Freung, A., Azaiza, F., Hertz-Lazarowitz, R., Boeum, A., \& Eshet, Y. (2015). School Climate and Teachers' Perceptions of Parental Involvement in Jewish and Arab Primary Schools in Israel. International Journal About Parents in Education 9(1), 77-92.

Schneider, B., \& Yongsook, L. (1990). A Model for Academic Success: The School and Home Environment of East Asian Student. Anthropology and Education Quarterly, 21(4), 358-377.

Scott, V. (1996). Rethinking Foreign Language Writing. Boston: Heinle \& Heinle Publishers.

Shanahan, T. (2002). What Reading Research Says: the promises and limitations of applying research to reading education. In A. Farstrup \& S. Samuels (Eds.), What Research Has to Say About Reading Instruction. USA: Reading Association.

Siegel, J. (2013). Second language learners' perceptions of listening strategy instruction. Innovation in Language Learning and Teaching, 7(1), 1-18.

Silva, T. (1993).Toward an Understanding of the Distinct Nature of L2 Writing: The ESL Research and Its Implications. TESOL Quarterly, 27, 657-677. doi: 10.2307/3587400.

Sudkamp, A., Kaiser, J., \& Moller, J. (2012). Accuracy of teachers' judgments of students' academic achievement: A meta-analysis. Journal of Educational Psychology, 104(3), 743-762.

Tatar, M. \& Horenczyk,G. (2003). Diversity-related burnout among teachers. Teaching and Teacher Education, 19, 397-408

Tejada, A., Pino, R., Tatar, M. \& M. Sayáns, P. (2012). Spanish as a foreign language" teachers' profiles: inclusive beliefs, teachers' perceptions of student outcomes in the TCLA program, burnout, and experience. European Journal of Psychology of Education, 27(3), 285-298.

Tsui, A. (2003).Understanding expertise in teaching: Case studies of second language teachers. Ernst Klett Sprachen.

Van Patten, B. (2007). Input Processing in Adult SLA. In B. Van Patten \& J. Williams (Eds.), Theories in Second Language Acquisition (pp. 113-134). Routledge.

Vandergrift, L. (2003). Orchestrating Strategy Use: Toward a Model of the Skilled Second Language Listener. Language Learning 53(3), 463-496.

Veenman, S. (1984). Perceived Problems of Beginning Teachers. Review of Educational Research, 54(2), 143178 .

Yoon, B. (2004). Uninvited Guests: The Influence of Teachers' Roles and Pedagogies on the Positioning of English Language Learners in the Regular Classroom. American Educational Research Journal, 5, 495-522.

Zeeland, H., \& Schmitt, N. (2013). Lexical Coverage in L1 and L2 Listening Comprehension: The Same or Different from Reading Comprehension? Applied Linguistics, 34 (4), 457-479. doi: 10.1093/applin/ams074. 